\title{
Impaired lymphocyte development and antibody class switching and increased malignancy in a murine model of DNA ligase IV syndrome
}

\author{
Anastasia Nijnik, ${ }^{1}$ Sara Dawson, ${ }^{2}$ Tanya L. Crockford, ${ }^{1}$ Lisa Woodbine, ${ }^{3}$ \\ Supawan Visetnoi, ${ }^{1}$ Sophia Bennett, ${ }^{1}$ Margaret Jones, ${ }^{4}$ Gareth D. Turner, ${ }^{4}$ \\ Penelope A. Jeggo, ${ }^{3}$ Christopher C. Goodnow, ${ }^{2}$ and Richard J. Cornall ${ }^{1}$
}

\begin{abstract}
${ }^{1}$ Henry Wellcome Building of Molecular Physiology, Oxford University, Oxford, United Kingdom. 22Australian Cancer Research Foundation Genetics Laboratory, Australian National University, and Australian Phenomics Facility, Canberra, Australian Capital Territory, Australia. ${ }^{3}$ Genome Damage and Stability Centre, University of Sussex, East Sussex, United Kingdom. ${ }^{4}$ Nuffield Department of Clinical and Laboratory Sciences, Oxford University, Oxford, United Kingdom.
\end{abstract}

\begin{abstract}
Hypomorphic mutations in DNA ligase IV (LIG4) cause a human syndrome of immunodeficiency, radiosensitivity, and growth retardation due to defective DNA repair by the nonhomologous end-joining (NHEJ) pathway. Lig4-null mice are embryonic lethal, and better mouse models are needed to study human LigIV syndrome. We recently identified a viable mouse strain with a Y288C hypomorphic mutation in the Lig4 gene. $L i g 4^{\mathrm{Y} 288 \mathrm{C}}$ mice exhibit a greater than 10 -fold reduction of LigIV activity in vivo and recapitulate the immunodeficiency and growth retardation seen in human patients. Here, we have demonstrated that the Lig ${ }^{\mathrm{Y} 288 \mathrm{C}}$ mutation leads to multiple defects in lymphocyte development and function, including impaired $\mathrm{V}(\mathrm{D}) \mathrm{J}$ recombination, peripheral lymphocyte survival and proliferation, and B cell class switch recombination. We also highlight a high incidence of thymic tumors in the Lig4 ${ }^{\mathrm{Y} 288 \mathrm{C}}$ mice, suggesting that wild-type LigIV protects against malignant transformation. These findings provide explanations for the complex lymphoid phenotype of human LigIV syndrome.
\end{abstract}

\section{Introduction}

Nonhomologous end joining (NHEJ) is one of the main pathways for repair of DNA double-strand breaks (DSBs) (1). The pathway comprises 6 core components: Ku70, Ku80, DNA-dependent protein kinase catalytic subunit (DNA-PK $\mathrm{Cs}_{\mathrm{c}}$, XRCC4, DNA ligase IV (LigIV) (1), and the recently discovered XRCC4-like factor (XLF) $(2,3)$. The end-joining process starts with the binding of $\mathrm{Ku} 70 /$ Ku 80 heterodimers to the DNA ends, followed by DNA-PK cs and other enzymes involved in end processing. LigIV is subsequently recruited to the DNA ends in complex with XRCC4 and, together with XLF, catalyzes the final end-joining reaction.

At least 10 hypomorphic mutations in the LIG4 gene have been identified in the human population, and in homozygous or compound heterozygous states, they cause a condition known as LigIV syndrome (4-11) (Supplemental Table 1; supplemental material available online with this article; doi:10.1172/JCI32743DS1). The clinical presentation of the syndrome is complex and heterogeneous and may include radiosensitivity, varying degrees of lymphopenia, growth retardation, and microcephaly (4-12). At the molecular level, all the features of the LigIV syndrome are thought to arise from impaired DNA DSB repair, and the complexity of the syndrome highlights the functions of the NHEJ pathway in many physiological processes.

Conflict of interest: The authors have declared that no conflict of interest exists. Nonstandard abbreviations used: CGG, chicken $\gamma$ globulin; DNA-PK $\mathrm{Cs}_{\mathrm{cs}}$ DNAdependent protein kinase catalytic subunit; DSB, DNA double-strand break; ENU, ethylnitrosourea; HEL, hen egg lysozyme; IgH, Ig heavy-chain locus; LigIV, DNA ligase IV; MEF, mouse embryonic fibroblast; NHEJ, nonhomologous end joining; NP, 4-hydroxy-3-nitrophenylacetyl aminoethylcarboxymethyl; TC, Tricolor; VHL, variable heavy light; XLF, XRCC4-like factor.

Citation for this article: J. Clin. Invest. 119:1696-1705 (2009). doi:10.1172/JCI32743
The embryonic lethality of the Lig4-null mouse strains $(13,14)$ limits their utility as models of LigIV syndrome. Other NHEJ-deficient strains - Ku70,Ku80, and $D N A-P K_{c s}$-null mice - are viable and share some of the phenotypic features of LigIV syndrome (15-19). However, the essential nature of Lig4 but not Ku70, Ku80, or DNA-PKcs attests to differing impact of these genes. Further, at the molecular level, the impact of these alleles is not equivalent to that of Lig4-null or -mutant alleles. For example, the functions of $\mathrm{Ku} 70, \mathrm{Ku} 80$, and DNA-PK $\mathrm{cs}_{\text {s }}$ are not limited to DNA DSB repair, and all 3 proteins are also required for normal telomere maintenance $(20,21)$. Additionally, residual DSB rejoining can occur in the absence of DNA-PK $\mathrm{PS}_{\mathrm{cs}}$ and, to a lesser extent $\mathrm{Ku}$, in $\mathrm{G}_{0}$ phase cells despite being LigIV dependent $(19,22)$. Furthermore, and possibly underlying the differences in DSB rejoining, the "accessibility" of DNA ends to alternative repair pathways is believed to differ in cells deficient in different NHEJ components $(23,24)$. The differences between $\mathrm{Ku}$ and LigIV deficiencies are further highlighted by the surprising observation that a loss of $\mathrm{Ku}$ can partly rescue the lethality of the Lig4-null strain (23). Thus, at least at the molecular level, some features of the previously characterized NHEJ-null mouse strains are distinct from those of the Lig4-null mouse and the human LigIV syndrome, suggesting that a LigIVmutant mouse strain is a more appropriate model for human LigIV syndrome than the existing NHEJ-deficient lines.

DNA DSBs can form as the result of random DNA damage and also during programmed DNA rearrangement events, namely $\mathrm{V}(\mathrm{D}) \mathrm{J}$ recombination and Ig class switching $(25,26)$. The phenotypic effects of impaired V(D)J rearrangement are widely known and account for a complete arrest in lymphocyte development in Lig4-null (13) and other NHEJ-null mice (15-19) and most likely 
A

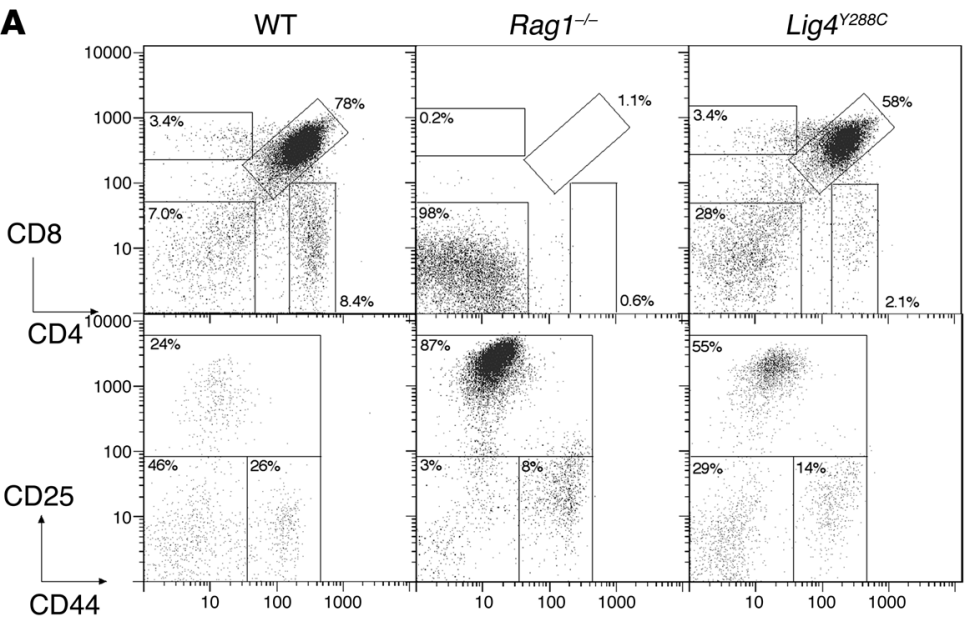

B

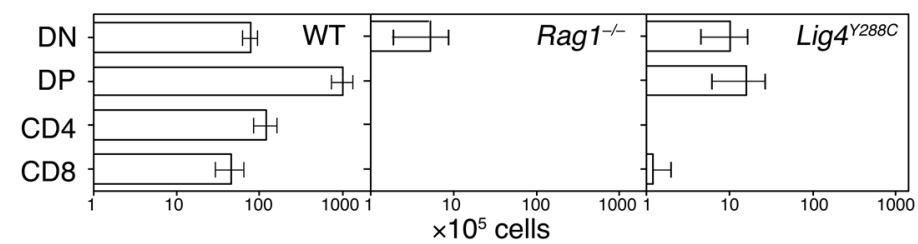

C

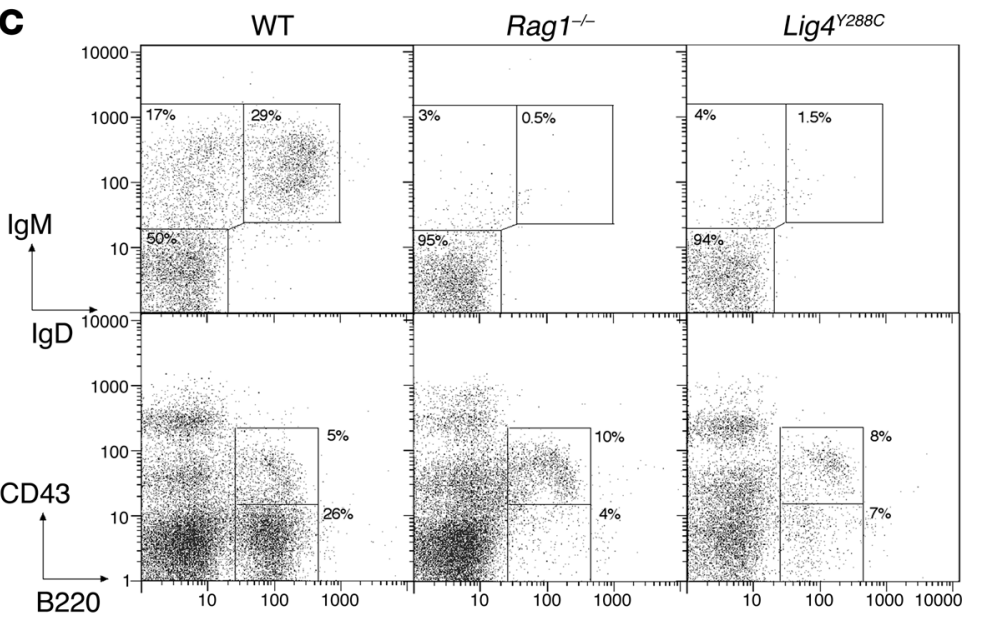

D

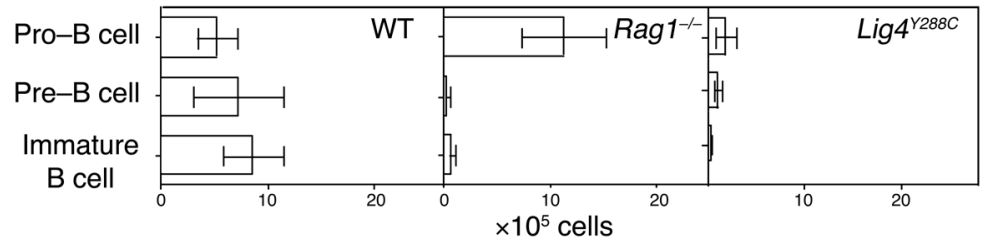

\section{Figure 1}

Partial arrest in lymphocyte development in Lig4 ${ }^{\text {Y288C }}$ strain. (A) Flow cytometry profiles of the thymus of WT, Rag $1^{-1-}$, and Lig $4^{\text {Y288C }}$ mice stained for CD4, CD8, CD44, and CD25 and gated on total thymocytes (upper panels) or CD4-CD8- double-negative thymocytes (lower panels). Numbers represent the percentages of cells in the plot that fall within the different regions, corresponding to different stages of thymocyte differentiation. (B) Absolute number of CD4-CD8- double-negative (DN), $\mathrm{CD}^{+}{ }^{+} \mathrm{CD} 8^{+}$doublepositive (DP), and CD4 and CD8 single-positive cells in

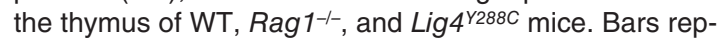
resent mean $\pm 95 \% \mathrm{Cl} ; n \geq 6$. (C) Flow cytometry of the bone marrow of WT, Rag $1^{-1-}$, and Lig $4^{\mathrm{Y} 288 \mathrm{C}}$ mice stained for B220, IgM, IgD (upper panels), or for B220 and CD43 (lower panels) and gated on $\mathrm{B}^{2} 20^{+}$cells or total lymphocytes, respectively. Numbers represent the percentages of cells in the plot that fall within the different regions, corresponding to different stages of $B$ cell differentiation. (D) Absolute numbers of $\mathrm{B} 220^{+} \mathrm{CD} 43^{+}$pro-B, B220 ${ }^{+} \mathrm{CD} 25^{+}$ pre- $\mathrm{B}$, and $\mathrm{B}_{2} 20^{+} \lg \mathrm{M}^{+} \lg \mathrm{D}^{-}$immature $\mathrm{B}$ cells in the bone marrow of WT, Rag1---, and Lig4 ${ }^{\mathrm{Y} 288 \mathrm{C}}$ (1 tibia and femur). Bars represent mean $\pm 95 \% \mathrm{Cl} ; n \geq 5$. also for the lymphopenia in LigIV syndrome $(4,6-8)$. The phenotypic effects of the impaired repair of nonprogrammed DNA damage are more diverse and difficult to study. They include the increased apoptosis in the developing brain causing the lethality of the Lig4-null mice $(13,14)$, the progressive decline in hematopoietic stem cells in the Lig $4^{\mathrm{Y} 288 \mathrm{C}}$ strain (27), and the impaired ex vivo lymphocyte proliferation $(28,29)$ and increased accumulation of chromosome breaks in the lymphocytes in LigIV syndrome (4). Although such defects in cell survival and proliferation are likely to have an impact on the immune system, their contribution to the immunodeficiency of the LigIV syndrome remains unknown.
Another physiological source of DNA DSBs is immunoglobulin class switching $(30,31)$, which is a somatic rearrangement of the Ig heavy-chain $(\operatorname{IgH})$ locus, occurring in B cells during the immune response and resulting in a switch in the antibody isotype. The DNA rearrangement is initiated by activation-induced deaminase, and the uracil lesions introduced by activation-induced deaminase into the switch-region DNA are processed to DSBs. Overwhelming evidence indicates that NHEJ has a role in the rejoining of the breaks, including evidence from the earlier studies of $K u$ - and $D N A-P K_{c s}$-null mice $(28,29,32-34)$ and the recent work on the conditional XRCC4 knockout, Lig $4^{-/-} p 53^{-/}$, and XLF-null mouse 


\section{Table 1}

Reduced lymphocyte numbers in the blood and peripheral lymphoid organs of Lig4Y288C mice

\begin{tabular}{|c|c|c|c|}
\hline \multirow[t]{3}{*}{ Genotype } & \multicolumn{3}{|c|}{ Total nucleated cells (\%) } \\
\hline & \multicolumn{3}{|c|}{ Blood } \\
\hline & B cell & $\begin{array}{l}\text { CD4 }^{+} \\
\text {T cell }\end{array}$ & $\begin{array}{l}\text { CD8 }{ }^{+} \\
\text {T cell }\end{array}$ \\
\hline $\begin{array}{l}\text { WT } \\
\text { Lig4Y288C }\end{array}$ & $\begin{array}{c}31 \pm 5 \\
2.9 \pm 0.7\end{array}$ & $\begin{array}{c}12 \pm 2 \\
1.8 \pm 0.3\end{array}$ & $\begin{array}{l}5.0 \pm 0.8 \\
1.5 \pm 0.2\end{array}$ \\
\hline
\end{tabular}

\begin{tabular}{|c|c|c|c|c|c|c|c|}
\hline \multicolumn{8}{|c|}{ Cell count $/ 10^{5}$ per mouse } \\
\hline \multicolumn{3}{|c|}{ Spleen } & \multicolumn{3}{|c|}{ Mesenteric lymph nodes } & \multicolumn{2}{|c|}{ Peritoneum } \\
\hline B cell & $\begin{array}{l}\mathrm{CD}^{+} \\
\text {T cell }\end{array}$ & $\begin{array}{l}\text { CD8 }^{+} \\
\text {T cell }\end{array}$ & B cell & $\begin{array}{l}\mathrm{CD}^{+} \\
\mathrm{T} \text { cell }\end{array}$ & $\begin{array}{l}\text { CD8 }{ }^{+} \\
T \text { cell }\end{array}$ & B2 cell & B1 cell \\
\hline $\begin{array}{c}754 \pm 148 \\
16 \pm 11\end{array}$ & $\begin{array}{c}251 \pm 62 \\
10 \pm 3\end{array}$ & $\begin{array}{c}141 \pm 42 \\
6 \pm 2\end{array}$ & $\begin{array}{c}114 \pm 62 \\
3 \pm 3\end{array}$ & $\begin{array}{c}125 \pm 40 \\
11 \pm 7\end{array}$ & $\begin{array}{c}80 \pm 25 \\
4 \pm 2\end{array}$ & $\begin{array}{l}2.23 \pm 1.7 \\
0.15 \pm 0.1\end{array}$ & $\begin{array}{l}2.35 \pm 0.5 \\
0.38 \pm 0.2\end{array}$ \\
\hline
\end{tabular}

Numbers indicate means $\pm 95 \% \mathrm{Cl} ; n \geq 9$. FACS plots representing B cell and CD4+ T cell populations in the blood previously published in ref. 27 .

strains, and a Lig4-null CH12F3 B cell lymphoma line (35-38). The recent studies indicate that, although NHEJ is involved, an alternative microhomology-mediated repair pathway can to some extent compensate, with residual levels of switching in the NHEJ-null B cells being as high as $25 \%-50 \%$ of the WT level. The alternative pathway was also implicated in class switching in the LigIV syndrome patients, based on the analysis of the structures of switch junctions (39). However, the quantitative impact of hypomorphic LigIV mutations on switching remains unknown.

Aberrant repair of DNA DSBs arising through any of the mechanisms described above could lead to chromosomal translocations, transformations, and cancer. Previous studies in mice indicate that the loss of NHEJ on its own results in only a mild predisposition to cancer in some strains (40-42). However, a combined loss of NHEJ and DNA damage cell-cycle checkpoints leads to a dramatic increase in lymphoid malignancies, as seen in the NHEJ-deficient $p 53^{-/-}$ mouse strains (43-45). In these mice, the tumors arise due to aberrant resolution of DNA DSBs during V(D)J recombination and carry translocations involving $\operatorname{IgH}$ and $c-m y c$ loci. Lymphomas were also reported in some LigIV syndrome patients $(5,8,9,11)$, although their frequency and the mechanism of carcinogenesis are difficult to ascertain. They may have arisen as a direct result of impaired DNA repair and genomic instability or as a secondary effect of immunodeficiency $(8,9)$. Furthermore, there may be significant bias in our estimates of lymphoma predisposition in this syndrome as, on the one hand, patients with severe forms of the disease commonly undergo bone marrow transplantation $(7,8,10)$, while on the other hand, some patients with milder forms of the condition are diagnosed with LigIV syndrome only following adverse responses to radio- or chemotherapy $(5,11)$.

We recently identified an ethylnitrosourea-induced (ENU-induced) hypomorphic mutation in the Lig4 gene in a mouse strain that displays the common features of the LigIV syndrome, including lymphopenia and growth retardation (27). The in vivo LigIV activity in the Lig $4^{Y 288 C}$ mice is reduced over 10-fold, similar to many of the LigIV syndrome patients $(4,46)$. One of the effects of the Lig $4^{\mathrm{Y} 288}$ mutation is a progressive attrition of hematopoietic stem cells in aged mice, although this is not limiting in young animals (27). Here, we provide a detailed characterization of the effects of the Lig4 ${ }^{\mathrm{Y} 288}$ mutation on the immune system: describing a severe defect in lymphocyte development, a partial arrest in B cell class switching,

\section{Figure 2}

and a defect in the survival of long-lived lymphocyte populations. Antibody responses to $\mathrm{T}$ cell-dependent and -independent antigens are dramatically impaired. We also describe the unexpectedly high incidence of thymic malignancies in the Lig $4^{\mathrm{Y} 288}$ mice and show that these can arise from aberrant resolution of $V(D) J$ breaks leading to translocation of the $\mathrm{T}$ cell receptor locus. These findings provide important insights into the underlying basis of immune pathology of LigIV syndrome.

\section{Results}

Partial arrest in lymphocyte development in the Lig4 ${ }^{\text {Y288C }}$ strain. The Lig $4^{\mathrm{Y} 28 \mathrm{C}}$ mouse line was identified in an ENU mutagenesis program as a recessive $\mathrm{C} 57 \mathrm{BL} / 6$ line with growth retardation and peripheral blood lymphopenia (27). The mice carry a Y288C substitution in the catalytic domain of LigIV, which reduces in vivo LigIV activity at least 10-fold and severely impairs the repair of DNA breaks
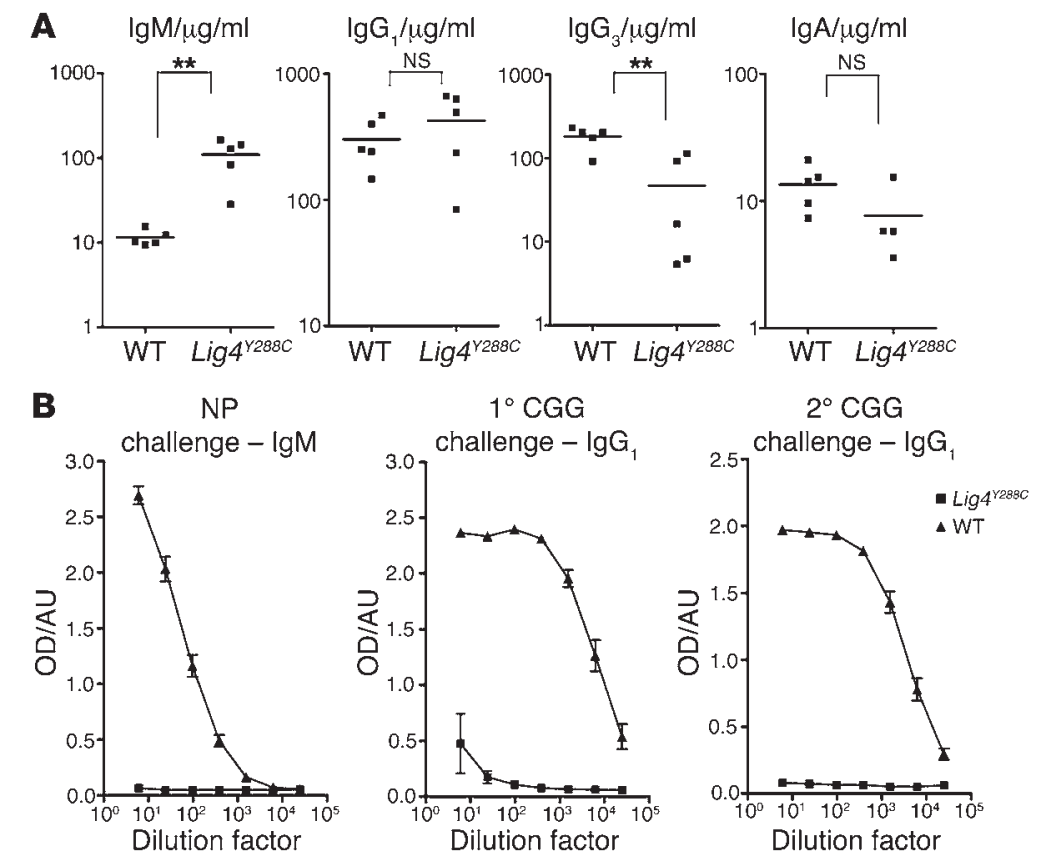

Impaired humoral immunity in Lig $4^{\mathrm{Y} 288 \mathrm{C}}$ mice. (A) Serum antibody isotype levels in naive WT and Lig $4^{\mathrm{Y} 288 \mathrm{C}}$ mice. Data points and bars represent the individual mice and the means of each dataset, respectively. (B) Antigen-specific antibody responses to T cell-independent (NP-Ficoll) and T cell-dependent (CGG) antigens in WT and Lig $4^{\mathrm{Y} 288 \mathrm{C}}$ mice (analyzed by ELISA, optical density plotted against the serum dilution factor). Error bars represent mean \pm SEM. ${ }^{* *} P<0.01$. 
A

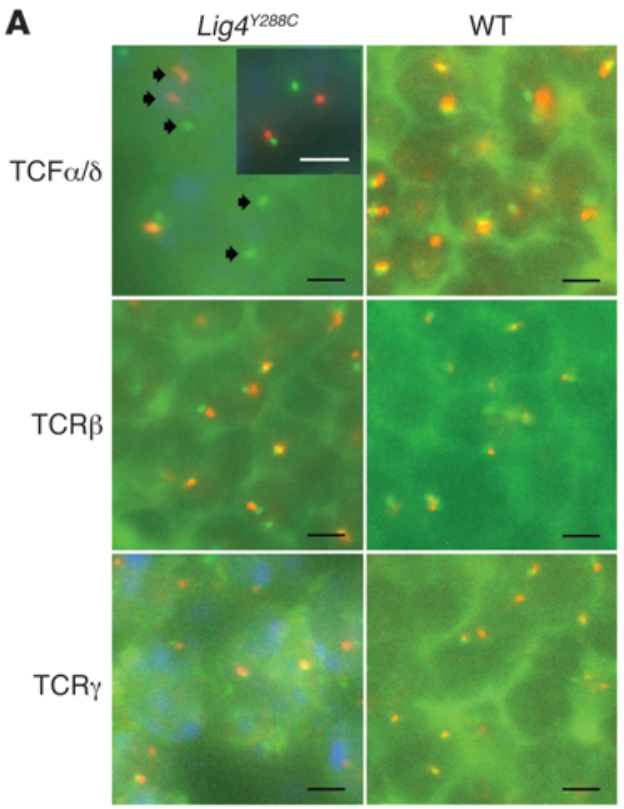

B
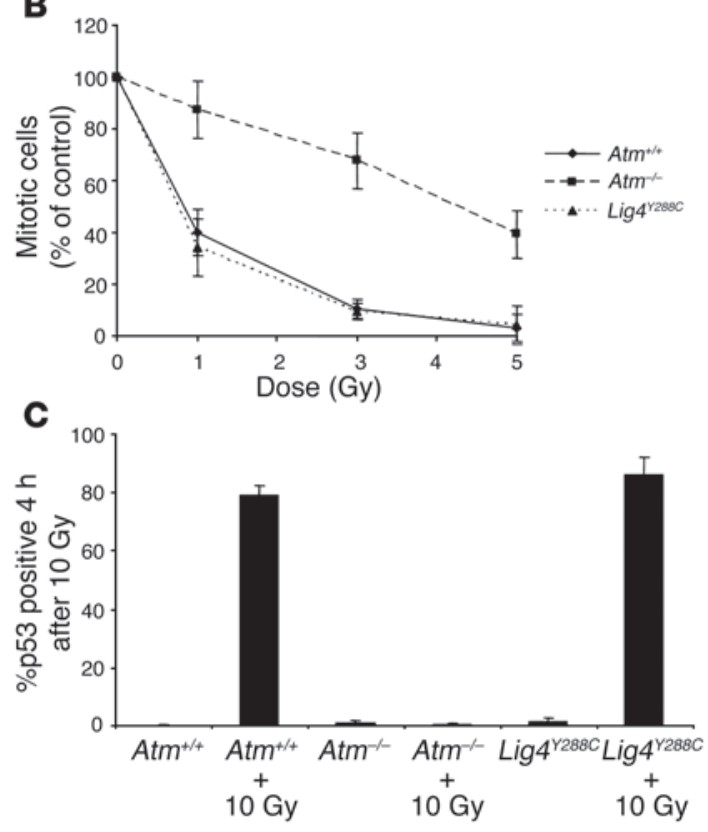

Figure 3

Thymic tumors in Lig $4^{\mathrm{Y} 288 \mathrm{C}}$ mouse. (A) Fluorescence in situ hybridization analysis of a Lig4 ${ }^{\mathrm{Y} 288 \mathrm{C}}$ thymic tumor and normal thymus of a WT mouse: loss of pairing of the TCR $\alpha / \delta$ flanking probes in cells of the Lig4 ${ }^{\mathrm{Y} 288 \mathrm{C}}$ thymic tumor (arrows) and in the inset section is indicative of chromosomal translocation at the locus. Scale bars: $5 \mu \mathrm{m}$. (B) Intact G2/M checkpoint in Lig4 ${ }^{\mathrm{Y} 288 \mathrm{C}} \mathrm{MEFs}$ : WT (Atm $\left.{ }^{+/+}\right)$, ataxia telangiectasia-mutated $\left(\right.$Atm $\left.^{-/-}\right)$, and Lig $4^{\mathrm{Y} 288 \mathrm{C}}$ MEFs were irradiated with 0 to $5 \mathrm{~Gy}$, and allowed to recover for 2 hours before analysis of mitotic index. Percentage of mitotic cells compared with nonirradiated cells is shown. Both $\mathrm{Atm}^{+/+}$and $\mathrm{Lig}^{\mathrm{Y} 288 \mathrm{C}}$ cells display an intact G2/M arrest in contrast with $\mathrm{Atm}^{-/-} \mathrm{MEFs}$, which continue to enter mitosis after irradiation. Error bars represent mean \pm SD. (C) Lig4 $4^{\mathrm{Y} 288 \mathrm{C}}$ MEFs activate p53 normally: MEFs were either nonirradiated or irradiated with $10 \mathrm{~Gy}$ and allowed to recover for 4 hours before processing. Percentage of cells positive for phosphorylated p53 was scored. Atm $^{+/+}$and Lig $4^{\mathrm{Y} 288 \mathrm{C}}$ MEFs have phosphorylated p53 after irradiation in contrast with Atm ${ }^{-/}$MEFs. Error bars represent means + $\mathrm{SD}$, from 3 independent experiments.

(27). The effects of the mutation at the molecular and cellular levels closely resemble those in human LigIV syndrome patients $(4,27)$.

We assessed the impact of the mutation on lymphocyte development by comparing primary lymphoid organs of Lig $4^{\mathrm{Y} 288 \mathrm{C}}$ mice with those of age-matched WT and Rag1-null mice, all on a C57BL/6 background. This revealed a severe but incomplete arrest in lymphocyte development in the Lig $4^{\mathrm{Y} 288 \mathrm{C}}$ strain (Figure 1). The total thymic cell count was 100 -fold lower than in the WT and comparable to that in the Rag $1^{-/-}$mice. The loss of thymocytes increased progressively at each developmental transition, and the proportion of thymocytes at the $\mathrm{CD} 25^{\text {hi }} \mathrm{CD}^{-}{ }^{-} \mathrm{CD}^{-}$stage preceding the onset of TCR $\beta$ rearrangement was increased, consistent with impaired $\mathrm{V}(\mathrm{D}) \mathrm{J}$ recombination $\left(\right.$ Lig $4^{\mathrm{Y} 288 \mathrm{C}}=48 \% \pm 1 \%$ and $\mathrm{WT}=26 \% \pm 6 \%$ of double-negative thymocytes, mean and 95\% CI; Figure 1, A and B).

The absolute numbers of pro- $\mathrm{B}\left(\mathrm{B} 220^{+} \mathrm{CD} 43^{+}\right)$, pre- $\mathrm{B}$ $\left(\mathrm{B} 220^{+} \mathrm{CD}_{25}\right)$, and immature $\mathrm{B}$ cells $\left(\mathrm{B} 220^{+} \operatorname{IgM} \mathrm{IgD}^{-}\right)$in the bone marrow of the $\operatorname{Lig}^{\mathrm{Y} 288 \mathrm{C}}$ mice also showed progressive cell loss, and a larger proportion of $\mathrm{B} 220^{+}$cells was arrested at the pro-B stage $\left(\operatorname{Lig} 4^{\text {Y2 } 28 C ~}=33 \% \pm 11 \%\right.$ and $\mathrm{WT}=13 \% \pm 4 \%$ of $\mathrm{B} 220^{+}$ bone marrow cells; Figure 1, C and D), consistent with impaired

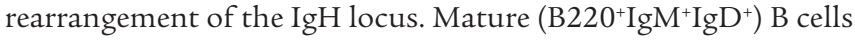
in the bone marrow could not be reliably detected but were found in low numbers in the periphery.

Lymphopenia and failure in antibody responses to challenge in the Lig4 ${ }^{Y 288 C}$ mice. The Lig4 ${ }^{\text {Y288C }}$ strain was originally identified based on the decreased frequency of recirculating lymphocytes (27), and the numbers of B and T cells in the blood of the Lig $4^{\mathrm{Y} 288 \mathrm{C}}$ mice were severely reduced (Table 1). Surprisingly, this was associated with elevated serum IgM (Figure 2A), which resembles some features of hyper-IgM immunodeficiencies seen in other DNA repair syndromes, particularly those affecting B cell class switching (12). Elevated IgM levels were also reported in some patients with mutations in LigIV and XLF $(2,8)$. Serum IgG 3 levels in the Lig4 ${ }^{Y 288 C}$ mice were significantly reduced, whereas serum $\operatorname{IgG}_{1}$ and $\operatorname{IgA}$ were comparable to those in WT (Figure 2A).

The numbers of $\mathrm{B}$ and $\mathrm{T}$ cells in the secondary lymphoid organs, such as the spleen and mesenteric lymph nodes, were severely reduced (Table 1). $\mathrm{CD}^{+}$and $\mathrm{CD}^{+} \mathrm{T}$ cells were 10 - to 25 -fold down in numbers and stained positive for TCR $\alpha \beta$. Interestingly, most $\mathrm{CD} 4^{+} \mathrm{T}$ cells had an activated phenotype with increased expression of CD44 and reduced CD45RB (Supplemental Figure 1). Such T cell activation is frequently seen in other partial $\mathrm{T}$ cell immunodeficiency syndromes in humans and mouse models, for example, in the Omenn syndrome, in which a reduction in $\mathrm{T}$ cell numbers caused by hypomorphic mutations in the RAG1/2 genes affects $T$ cell tolerance and activation, probably by reducing competition for limiting amounts of prosurvival cytokines or costimulatory molecules (reviewed in refs. 47, 48).

The absolute numbers of B cells in the secondary lymphoid organs were reduced nearly 50 -fold (Table 1 ), with a large relative increase in the proportion of transitional B cells $\left(\mathrm{B} 220^{+} \mathrm{CD} 23^{-}\right.$ CD21-). The transitional B cell population constituted $86 \% \pm 7 \%$ of $\mathrm{B} 220^{+}$splenocytes in the Lig $4^{\mathrm{Y} 288 \mathrm{C}}$ mice compared with only $32 \%$ 
A

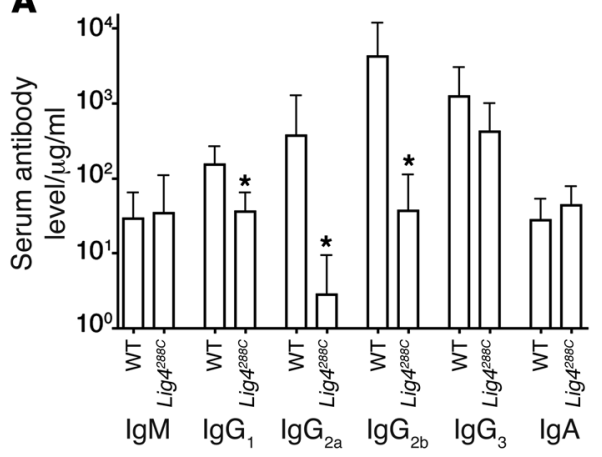

B

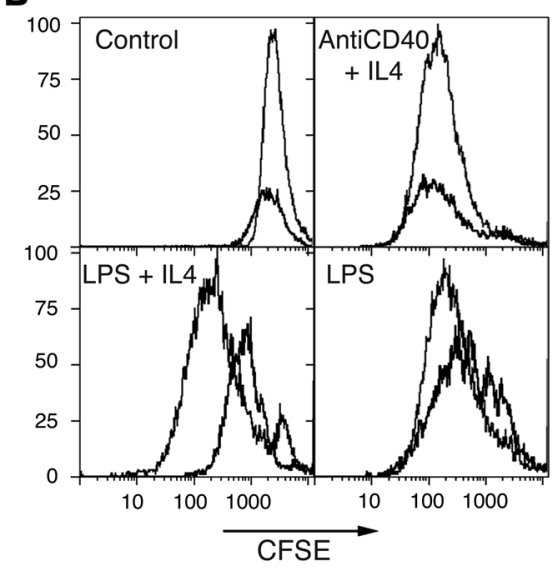

D

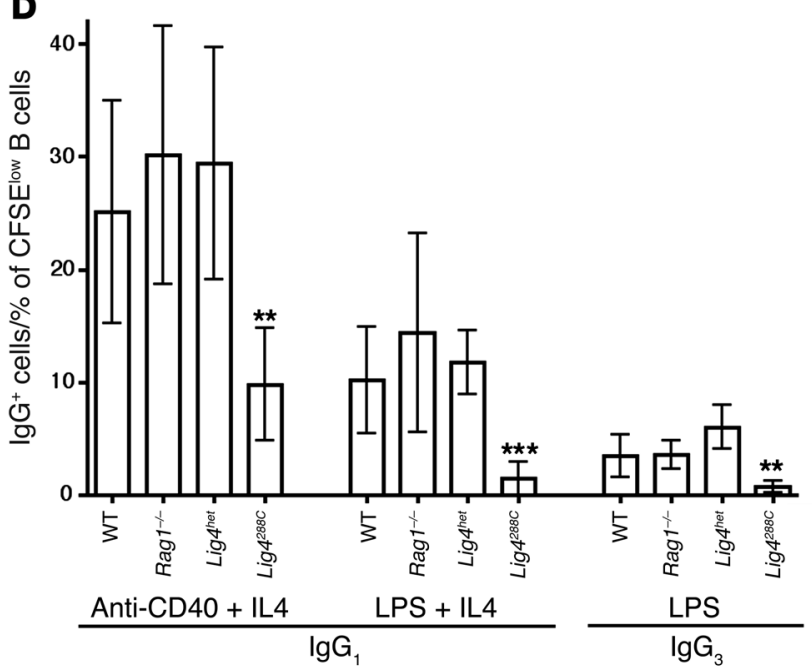

C

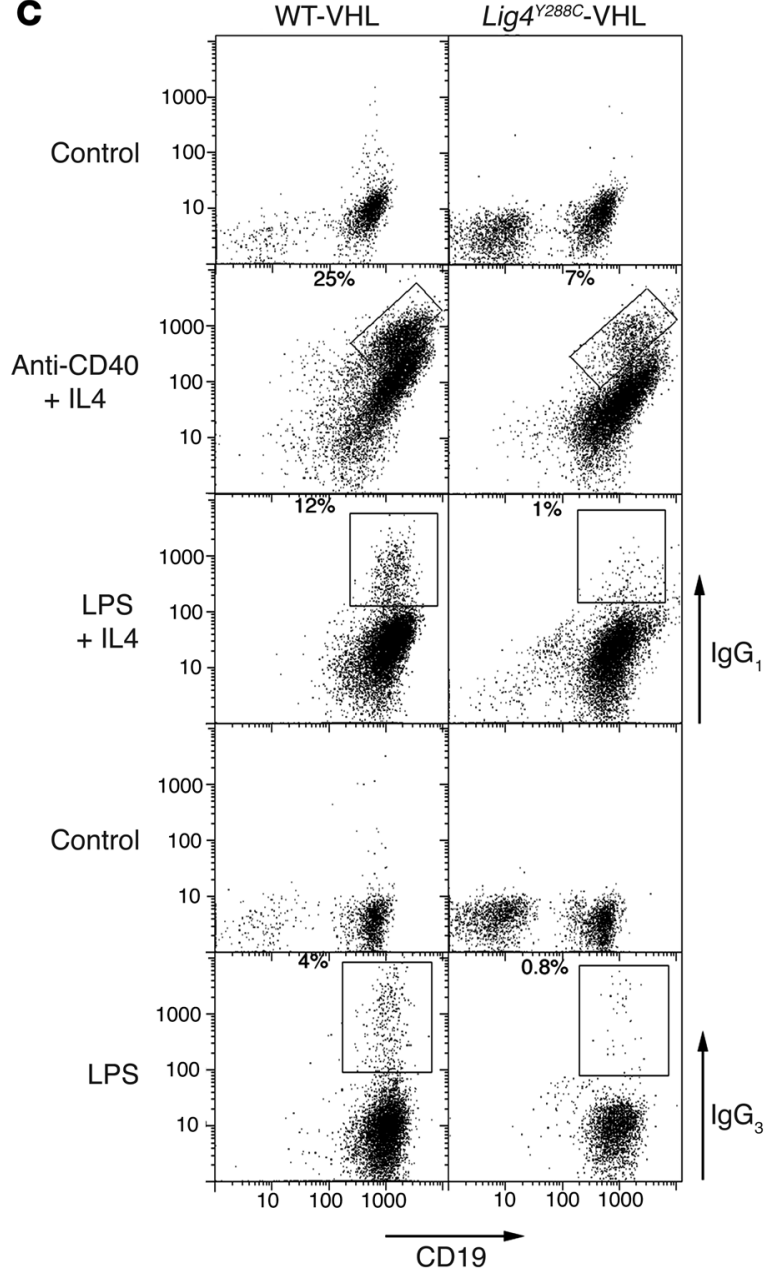

Figure 4

Partial defect in immunoglobulin class switching in Lig4 ${ }^{\mathrm{Y} 288 \mathrm{C}}$ mice. (A) Anti-HEL antibody levels in the serum of WT-VHL (WT) and Lig4 ${ }^{\mathrm{Y} 288 \mathrm{C}-\mathrm{VHL}}$ $\left(\right.$ Lig4 ${ }^{\mathrm{Y} 288 C}$ ) mice. Bars represent geometric means and $95 \% \mathrm{Cl}, n \geq 3$; comparisons by Mann-Whitney test, ${ }^{*} P<0.05$. (B-D) Class switching of Lig4 ${ }^{\mathrm{Y} 288 \mathrm{C}-\mathrm{VHL}}$ and control WT-VHL B cells at day 4 of in vitro stimulation with LPS, LPS plus IL-4, and anti-CD40 plus IL-4. (B) CFSE fluo-

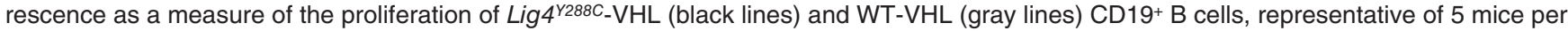
group. (C) CD19+ versus IgG flow cytometry profiles of WT-VHL and Lig $4^{\mathrm{Y} 288 \mathrm{C}}$-VHL splenocytes gated on the highly proliferated CFSE-low cells. Numbers indicate the percentages of class-switched B cells within each plot. (D) IgG+ cells as a percentage of the highly proliferated CFSE-low CD19+ B cells in Lig 4Y288C-VHL, WT-VHL, Lig4+/Y288C-VHL (Lig4het), and Rag 1-l--VHL cultures at day 4 of in vitro stimulation. Error bars represent means $\pm 95 \% \mathrm{Cl} ; n=6$ for WT and $\operatorname{Lig} 4^{\mathrm{Y} 288 \mathrm{C}} ; n=3$ for $\operatorname{Lig} 4^{\text {het }}$ and $\operatorname{Rag}^{-1-}{ }^{\star \star \star} P<0.01 ;{ }^{* \star \star} P<0.001$ using ANOVA. 

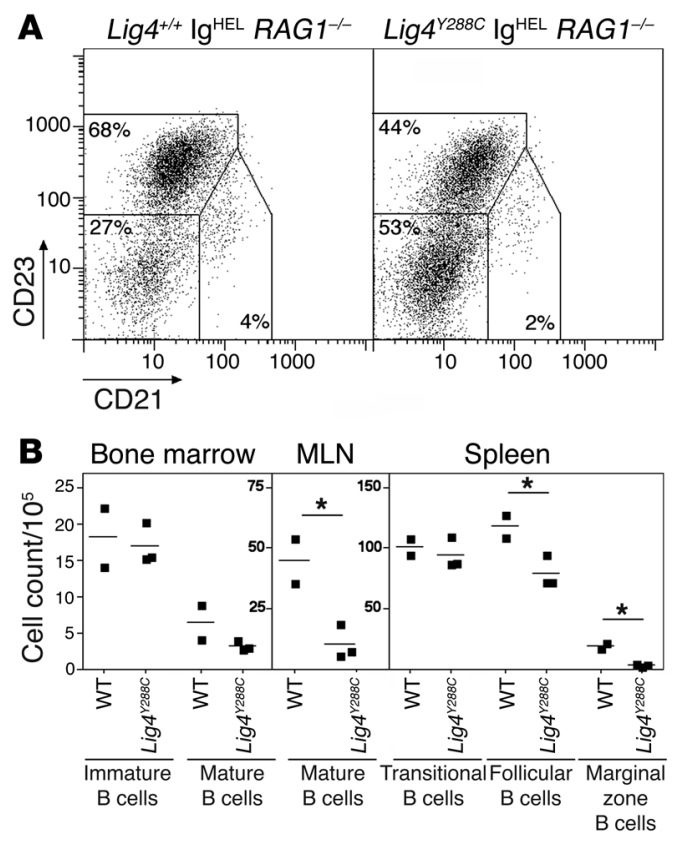

$\pm 14 \%$ in the WT (data not shown). This suggested that further loss of B cells may have been occurring in the peripheral lymphoid organs after the cells progressed from the transitional to the mature stage, as demonstrated later in this study.

In the peritoneal cavity, despite a large reduction in conventional $\operatorname{IgM}^{\mathrm{lo}} \mathrm{B} 220^{\text {hi }} \mathrm{B} 2$ cells, a considerable population of $\operatorname{IgM}^{\text {hi }} \mathrm{B} 220^{\mathrm{lo}} \mathrm{B} 1$ cells was retained (Table 1 and Supplemental Figure 2A). These cells had the typical phenotype of B1 cells - high forward scatter, low expression of IgD, higher expression of CD9, MAC1, and CD43and were also $\mathrm{CD}^{+}$(Supplemental Figure 2B). In scid ${ }^{\mathrm{DNA}-\mathrm{PKcs}}$ mice, B1 cells were previously associated with serum autoantibodies (49), and autoantibodies and autoimmune thrombocytopenia were also reported in some LigIV patients (8). Thus, we analyzed Lig $4^{\mathrm{Y} 288 \mathrm{C}}$ for serum autoantibodies. We observed some increase in the incidence of IgM autoantibodies largely targeting cytosolic proteins; however, no IgG autoantibodies were found (Supplemental Figure 2C).

To further characterize the immunodeficiency in the Lig4 ${ }^{Y 288 C}$ strain, we assessed humoral responses to challenge with T celldependent (chicken $\gamma$ globulin [CGG]) and T cell-independent (4-hydroxy-3-nitrophenylacetyl aminoethylcarboxymethyl-Ficoll [NP-Ficoll]) antigens. We observed an almost complete loss of antibody responses in Lig4 ${ }^{\mathrm{Y} 288 \mathrm{C}}$ mice (Figure 2B), consistent with the reported failure of several LigIV patients to mount antibody responses to immunization or infection (8). This highlights the dramatic impairment in humoral immunity in the LigIV syndrome, which likely arises from severe lymphopenia together with additional defects in Ig class switching, cell proliferation, and survival, as reported later in this study.

Increased incidence of thymic tumors in the Lig $4^{\mathrm{Y} 288 \mathrm{C}}$ mice. The Lig $4^{\mathrm{Y} 288 \mathrm{C}}$ mice showed high incidence of lymphoid malignancies. Malignancies were found in 12 out of $45 \mathrm{Lig} 4^{\mathrm{Y} 288 \mathrm{C}}$ mice analyzed, compared with none of the WT or Lig $4^{\mathrm{Y} 288 \mathrm{C} /+}$ littermates. In 8 of 12 of the affected animals, the malignancies were of thymic origin and $\mathrm{CD} 4^{+} \mathrm{CD}^{+}$ cell surface profile, and in 1 mouse, the malignant cells were of B220lo $\operatorname{IgM}^{\text {hi }}$ B1 cell phenotype and spread in the peritoneum and spleen. Some of the affected mice were as young as 6 weeks.

\section{Figure 5}

Impaired peripheral lymphocyte survival contributes to immunodeficiency in Lig $4^{\mathrm{Y} 288 \mathrm{C}}$ mice. (A) Flow cytometry profiles of the spleen of

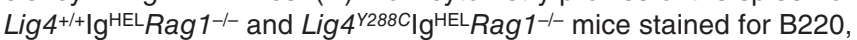
CD21, and CD23 and gated on B220+ cells. Numbers indicate the percentages of splenic B cells within the transitional CD21-CD23-, follicular CD21 ${ }^{+} \mathrm{CD} 23^{+}$, and marginal zone $\mathrm{CD} 21^{\text {hi }} \mathrm{CD} 23^{\text {lo }}$ gates. (B) Absolute number of $B$ cells in the bone marrow, mesenteric lymph nodes (MLN), and spleen of $\mathrm{Lig}^{+/+} \mathrm{Ig}^{\mathrm{HEL}} \mathrm{Rag}^{1^{-/-}}$(WT) and Lig $4^{\mathrm{Y} 288 \mathrm{C}} \mathrm{Ig}^{\mathrm{HEL}} \mathrm{Rag}$ 1 $^{-/-}$ $\left(L i g 4^{\mathrm{Y} 288 \mathrm{C}}\right)$ mice. Data points and bars represent individual mice and the mean of each dataset, respectively. Bone marrow immature $B$ cells were gated as $\mathrm{B} 22 \mathrm{O}^{+} \operatorname{lgM}+\mathrm{HSA}^{\text {hi }}$ and mature $\mathrm{B}$ cells as $\mathrm{B} 22 \mathrm{O}^{+} \lg \mathrm{M}+\mathrm{HSA} \mathrm{A}^{\mathrm{lo}}$; splenic transitional $\mathrm{B}$ cells were gated as $\mathrm{B} 220^{+} \mathrm{CD} 21^{-} \mathrm{CD} 23^{-}$, follicular as $\mathrm{B} 22 \mathrm{O}^{+} \mathrm{CD} 21^{+} \mathrm{CD}_{23}{ }^{+}$, and marginal zone as B220 ${ }^{+} \mathrm{CD} 21^{\text {hi }} \mathrm{CD} 23^{\mathrm{lo}}$; B cells in the MLN were gated as $B 220^{+} \operatorname{lgM}{ }^{+} \lg D^{+}$. ${ }^{*} P<0.05$, 2-tailed Student's $t$ test.

To analyze the mechanisms that lead to carcinogenesis, we studied 1 of the thymic tumors for chromosomal translocations involving TCR loci by looking for evidence of separation of red and green FISH probe pairs derived from BACs flanking the TCR $\alpha / \delta,-\beta$, and $-\gamma$ loci. In this way, we found chromosomal separation of $54 \%(216 / 398)$ of $\mathrm{TCR} \alpha / \delta$ probes in the tumor cells, indicative of a translocation (Figure $3 \mathrm{~A}$ ). This observation suggests that thymic tumors in the LigIV syndrome can arise from aberrant resolution of DNA breaks at the TCR locus, probably during V(D)J recombination.

The high incidence and early age of onset of tumors in Lig $4^{\text {Y288C }}$ mice was unexpected. In other NHEJ-deficient mouse strains, a high incidence of cancer typically results from a combined defect in DNA repair and cell-cycle checkpoints, such as in the NHEJ-deficient $p 53^{-/-}$mouse strains (43-45). Thus, we analyzed the effects of the Lig4 $4^{Y 288 C}$ mutation on G2/M cell cycle checkpoint arrest and on p53 phosphorylation in mouse embryonic fibroblasts (MEFs). The data show that Lig4 ${ }^{\text {Y288C }}$ MEFs undergo normal G2/M cell-cycle arrest and phosphorylate p53 normally following irradiation (Figure $3, \mathrm{~B}$ and $\mathrm{C}$ ), which is consistent with previous findings from Lig4 $4^{-/-}$MEFs and the cells of LigIV syndrome patients $(4,13)$.

The role of LigIV in $B$ cell receptor class switching. To assess the impact of the Lig $4^{\mathrm{Y} 288 \mathrm{C}}$ mutation on B cell class switching, we crossed the following B cell receptor transgenes onto the Lig $4^{Y 288 C}$ line to generate Lig4 ${ }^{\text {Y288C }}$-VHL (where VHL indicates variable heavy light) mice: an anti-hen egg lysozyme (anti-HEL) $\kappa$ light chain transgene and an "IgH knockin" that is capable of switching. To increase litter sizes, the cross was on a mixed C57BL/6×NOD background and agematched littermates were used as controls in all the comparisons to minimize any differences in genetic background between the groups. In VHL mice, the vast majority of B cells showed specificity for HEL, and the VHL transgene resulted in a partial rescue of B cell development and peripheral B cell numbers in the Lig4 ${ }^{\mathrm{Y} 288 \mathrm{C}} \mathrm{V} \mathrm{VHL}$ mice. Thus, the average number of HEL-binding B cells in the spleen of the Lig4 ${ }^{\mathrm{Y} 288 \mathrm{C}_{-} \mathrm{VHL}}$ mice was $3.3 \times 10^{6}$, compared with $0.7 \times 10^{6} \mathrm{~B}$ cells in the nontransgenic Lig4 ${ }^{Y 288 C}$ and $23 \times 10^{6} \mathrm{~B}$ cells in the WTVHL controls. We also measured serum anti-HEL antibody levels in the Lig4 ${ }^{Y 288 C}$-VHL mice: $\operatorname{IgG}_{1}, \operatorname{IgG}_{2 \mathrm{a}}$, and $\mathrm{IgG}_{2 \mathrm{~b}}$ levels were significantly reduced relative to WT-VHL $(P<0.05)$, but $\operatorname{IgM}, \operatorname{IgG}_{3}$, and IgA titers were within normal range (Figure $4 \mathrm{~A}$ ).

We chose to assess Ig class switching in an in vitro system, using the previously described protocols that provide a control for reduced $\mathrm{B}$ cell number, reduced provision of $\mathrm{T}$ cell help, and any changes in $\mathrm{B}$ cell proliferation $(33,36,50,51)$. Specifically, cell proliferation in the Lig4 ${ }^{Y 288 C}$ strain was assessed and controlled for using CFSE labeling. 


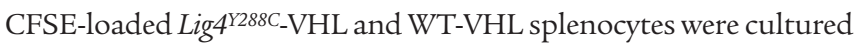
for 4 days with LPS, LPS plus IL-4, or anti-CD40 plus IL-4. The

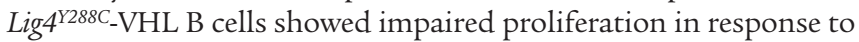
LPS and LPS plus IL-4 stimulation, but surprisingly, proliferation in response to anti-CD40 plus IL-4 stimulation was normal (Figure 4B). To control for differences in cell proliferation, highly proliferated CFSE $^{\text {lo }}$ cells were gated, and the proportions of switched $\operatorname{IgG}^{+} \mathrm{B}$ cells

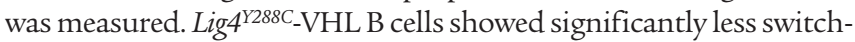
ing to $\mathrm{IgG}_{1}$ and $\mathrm{IgG}_{3}$ with all 3 classes of stimuli (Figure 4, C and D). Thus, switching to $\mathrm{IgG}_{1}$ in response to LPS plus IL-4 was reduced from $10 \% \pm 5 \%$ in WT-VHL to $1.4 \% \pm 1.5 \%$ in ig $^{\mathrm{Y} 288 \mathrm{C}}$-VHL, and switching to $\mathrm{IgG}_{3}$ in response to LPS was reduced from $3.5 \% \pm 1.9 \%$ to $0.7 \% \pm 0.5 \%(P<0.001$ and $P<0.01$, respectively). Importantly, switching in cultures stimulated with anti-CD40 plus IL-4, where there was no difference in cell proliferation, was also significantly reduced, from $25 \% \pm 10 \%$ to $10 \% \pm 5 \%(P<0.01)$, confirming that the impaired switching is not a side effect of low proliferation.

To account for the differences in $\mathrm{T}$ cell numbers in the cultures and for possible differences in B cell repertoire that could arise through B cell receptor editing, we used Rag1-VHL (VHL-knockin, Rag1 $1^{-/}$, Lig $^{+/+}$) controls. Using ANOVA, we found no difference in switching between WT-VHL and Rag1-VHL cultures, suggesting that the above factors have no effect, whereas Lig4 ${ }^{Y 288 C}$-VHL switching was reduced relative to both control groups (Figure 4D).

Impaired peripherallymphocyte survival contributes to immunodeficiency. To assess the impact of the impaired repair of background DNA damage on lymphocyte survival, we created a system in which the Lig4 ${ }^{\text {Y288C }}$ B cells could develop without undergoing V(D)J rearrangement or Ig class switching. To achieve this, we crossed the MD4 $\mathrm{Ig}^{\mathrm{HEL}}$ transgene and the Rag1-null allele onto the Lig4 ${ }^{\mathrm{Y} 288 \mathrm{C}}$ strain to generate $\mathrm{Lig}^{\mathrm{Y} 288 \mathrm{C}} \mathrm{Ig}^{\mathrm{HEL}} \mathrm{Rag} 1^{-/-}$mice. These mice were compared with age-matched $\operatorname{Lig} 4^{+/+} \operatorname{Ig}^{\mathrm{HEL}} \mathrm{Rag} 1^{-/-}$littermates, all on an inbred C57BL/ 6 background. In these mice, the rearrangement of the endogenous immunoglobulin loci is prevented by the lack of RAG-1, and all B cells express the transgenic MD4 B cell receptor, which does not undergo class switching. Furthermore, both groups of mice lack T cells, controlling for indirect effects of $\mathrm{T}$ lymphocytes on B cell turnover.

Analysis of the mice showed no differences in the numbers of immature (B220 $\left.\operatorname{IgM}^{+} \mathrm{HSA}^{\text {hi }}\right) \mathrm{B}$ cells in the bone marrow or transitional $\left(\mathrm{B} 220^{+} \mathrm{CD} 21^{-} \mathrm{CD} 23^{-}\right) \mathrm{B}$ cells in the spleen between the Lig $4^{\mathrm{Y} 288 \mathrm{C}}$ and $\mathrm{Lig} 4^{+/+}$groups (Figure 5, A and B), which demonstrates that the impaired B cell development in the Lig4 ${ }^{\mathrm{Y} 288 \mathrm{C}}$ mutant is entirely limited by a defect in $\mathrm{V}(\mathrm{D}) \mathrm{J}$ rearrangement. However, the numbers of long-lived B cell populations, such as the follicular $\left(\mathrm{B} 220^{+} \mathrm{CD} 21^{+} \mathrm{CD} 23^{+}\right)$and marginal zone $\left(\mathrm{B} 220^{+} \mathrm{CD} 21^{\mathrm{hi}} \mathrm{CD} 23^{\mathrm{lo}}\right)$ $\mathrm{B}$ cells in the spleen and mature $\mathrm{B}$ cells in the mesenteric lymph nodes $\left(\mathrm{B} 220^{+} \mathrm{IgM}^{+} \mathrm{IgD}^{+}\right)$, were reduced in the $\operatorname{Lig} 4^{\mathrm{Y} 288 \mathrm{C}} \mathrm{Ig}^{\mathrm{HEL}} \mathrm{Rag} 1^{-\gamma^{-}}$ mice compared with the $\mathrm{Lig}^{+/+} \mathrm{Ig}^{\mathrm{HEL}} \mathrm{Rag}^{1^{-/}}$controls (Figure $5 \mathrm{~B}$ ). The number of mature $\left(\mathrm{B} 220^{+} \operatorname{IgM}{ }^{+} \mathrm{HSA}^{\mathrm{lo}}\right) \mathrm{B}$ cells in the bone marrow was also lower in the mutants, though the difference did not reach statistical significance (Figure 5B). This indicates a biologically important function of NHEJ in the maintenance of genomic stability in peripheral lymphocytes, independent of its roles in $\mathrm{V}(\mathrm{D}) \mathrm{J}$ rearrangement and class switching, and suggests that impaired peripheral lymphocyte survival contributes to the immunodeficiency in the LigIV syndrome.

Increased turnover of lymphocytes in the secondary lymphoid organs of the Lig $4^{\mathrm{Y} 288}$ mice was confirmed by a BrdU-incorporation assay. Nontransgenic WT and Lig $4^{\mathrm{Y} 288}$ mice were fed BrdU at
$0.25 \mathrm{mg} / \mathrm{ml}$ in drinking water for 1 week, and after this period, $66 \% \pm 23 \%$ of B cells and $62 \% \pm 5 \%$ of T cells in the spleen of the Lig ${ }^{\mathrm{Y} 288 \mathrm{C}}$ mice stained $\mathrm{BrdU}^{+}$compared with only $31 \% \pm 6 \%$ of $\mathrm{B}$ cells and $19 \% \pm 5 \%$ of T cells in the WT group; and a similar difference was seen in the mesenteric lymph nodes.

\section{Discussion}

The hypomorphic mouse strain Lig $4^{\mathrm{Y} 288 \mathrm{C}}$ generated in an ENU mutagenesis program is, we believe, the first viable animal model of the LigIV syndrome. Like LigIV syndrome patients, the Lig $4^{\text {Y288C }}$ mice show an over 10-fold reduction in LigIV activity and similar general phenotypic features of growth retardation and lymphopenia. In this study, we provide a detailed analysis of the effects of the hypomorphic LigIV deficiency on the mammalian immune system. This demonstrates how the generation of point mutations by ENU mutagenesis mimics naturally occurring hypomorphic mutations and allows an investigation of gene functions that are masked by embryonic lethality in gene-knockout lines.

We report profound immunodeficiency in Lig4 ${ }^{Y 288 C}$ mice, with primary and secondary lymphoid organ lymphopenia. Surprisingly, $\operatorname{IgG}_{1}$ and $\mathrm{IgA}$ (but not $\mathrm{IgG}_{3}$ ) antibody isotypes in Lig4 $4^{\mathrm{Y} 28 \mathrm{C}}$ serum are maintained at normal levels, despite the very low numbers of peripheral B cells and impaired Ig class switching, which suggest that compensatory mechanisms must be present. These might operate at the level of B cell selection, $T$ cell activation, competition for other B cell and plasma cell survival factors, or antibody clearance. When immunized, the $\operatorname{Lig} 4^{\mathrm{Y} 288 \mathrm{C}}$ mice show an almost complete loss of antigen-specific antibody responses to $\mathrm{T}$ cell-dependent and $\mathrm{T}$ cell-independent antigens. This resembles features of the human LigIV syndrome $(6,8)$ and highlights the dramatic loss of immune system function caused by the LigIV mutations. We further demonstrate that, in addition to the wellcharacterized arrest in $\mathrm{V}(\mathrm{D}) \mathrm{J}$ rearrangement, impaired survival of long-lived lymphocyte populations also contributes to immunodeficiency. By creating a system in which Lig $4^{\text {Y288C }}$ B cells develop without undergoing $\mathrm{V}(\mathrm{D}) \mathrm{J}$ rearrangement or class switching and controlling for $\mathrm{T}$ cell numbers, we demonstrate the impact of background DNA damage on these long-lived lymphocyte populations and the role of NHEJ in their maintenance. We also report overall activation of peripheral T cells, retention of B1 cells, and some increase in IgM autoantibodies in the Lig $4^{\mathrm{Y} 288 \mathrm{C}}$ mice. These phenotypes have not been previously assessed in any of the LigIV syndrome patients; however, autoimmune thrombocytopenia was seen in at least 1 patient and also in patients with mutations in $\mathrm{XLF}(2,8)$, suggesting that $\operatorname{IgM}$ autoantibodies may be relevant in NHEJ deficiency syndromes.

We show impaired class switching in Lig $4^{Y 288 C}$ B cells, demonstrating the involvement of LigIV and the NHEJ pathway in the class switching reaction. This confirms the recent conclusions of

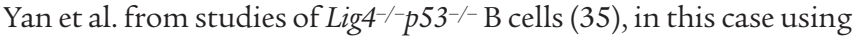
LigIV-deficient B cells without additional defects in DNA damage response pathways. Our experimental system directly assesses switching at the cellular level and shows that Lig4 ${ }^{\mathrm{Y} 288 \mathrm{C}} \mathrm{B}$ cells are defective in class switching to 2 different antibody isotypes with 3 different stimuli, and this is independent of differences in B cell proliferation, B cell receptor specificity, or T cell help. Some switching in Lig $4^{\mathrm{Y} 288 \mathrm{C}}$ is probably due to the residual activity of LigIV, with possible contributions of alternative repair pathways $(35,39)$. However, despite the contribution of alternative repair pathways to class switching $(35,39)$, our findings show that hypomorphic 
mutations in LigIV can significantly impair B cell class switching and contribute to the immunodeficiency of LigIV syndrome.

We further report an unexpectedly high incidence of $\mathrm{CD} 4^{+} \mathrm{CD} 8^{+}$ thymic tumors in Lig $4^{\mathrm{Y} 288 \mathrm{C}}$ mice, suggesting that LigIV deficiency predisposes to malignancies. The Lig $4^{Y 288 C}$ tumors are associated with chromosomal translocations at the TCR $\alpha / \delta$ locus, probably caused by aberrant repair of RAG-induced DNA breaks. The strong predisposition to cancer in Lig $4^{Y 288 C}$ mice suggests that the mutations that similarly impair LigIV activity in humans will also predispose to cancer and that $\mathrm{T}$ cell leukemias reported in some LigIV syndrome patients may arise through similar mechanisms $(5,11)$. This conclusion is of clinical interest, as the DNA repair deficiency is associated with adverse response to radio- and chemotherapy in this group of cancer patients $(5,11)$. It also further highlights the possibility that small alterations in LigIV activity in heterozygous carriers of Lig4 mutations may predispose to cancer, as suggested by the fact that Lig4 haploinsufficiency increases the frequency of soft-tissue sarcomas in INK4a/ARF-null mice (52) and by the association of a human LIG4 polymorphism with increased risk of lung carcinomas (53).

The high cancer susceptibility of the Lig ${ }^{\text {Y288C }}$ line compared with other NHEJ-deficient mouse strains is surprising, as it is widely believed that defects in NHEJ repair lead to carcinogenesis only when combined with loss of cell-cycle checkpoints, as in the NHEJ-deficient $p 53^{-/-}$strains (42-45). Although $\mathrm{Ku} 70^{-/-}$mice were reported to develop $\mathrm{CD} 4^{+} \mathrm{CD}^{+}$lymphomas similar to those of $\operatorname{Lig} 4^{\text {Y288C }}$ mice (54), this was disputed in recent reports arguing that both $\mathrm{Ku}_{70^{-/-}}$and $\mathrm{Ku} 80^{-/-}$strains are not tumor prone $(40,55)$. Furthermore, Lig4-/- $p 53^{R 172 P / R 172 P}$ mice with a defect in DNA damage apoptosis induction but normal cell-cycle arrest are tumor free (56). In contrast, we observed high rates of leukemia in Lig $4^{Y 288 C}$ mice despite normal G2/M checkpoint arrest and normal p53 activation, and the reason for increased cancer predisposition in Lig4 ${ }^{Y 288 C}$ compared with other NHEJ-null mouse strains is unknown. We can speculate that because the tumors arise from the $\mathrm{CD}^{+} \mathrm{CD}^{+}$population, progression of some thymocytes to the $\mathrm{CD}^{+} \mathrm{CD}^{+}$stage may be a prerequisite for carcinogenesis. Thus, the increased incidence of malignancies in the Lig4 ${ }^{\text {Y288C }}$ mice may be the result of the hypomorphic nature of the phenotype that allows some "leaky" $\mathrm{T}$ cell development to take place, as is also seen in the tumor-prone and "leaky" $\mathrm{Ku} 70^{-/-}$ line (54). It is also possible to speculate that the accessibility of DNA breaks to alternative error-prone repair pathways may differ between the different NHEJ-deficient mouse lines, leading to increased predisposition to aberrant repair and translocations in some of the lines, such as Lig ${ }^{\mathrm{Y} 288 \mathrm{C}}$. Although many questions remain unanswered, our findings with $\operatorname{Lig} 4^{\text {Y288C }}$ mice provide definitive evidence that hypomorphic LigIV deficiencies can predispose to leukemia.

In summary, access to the ENU-induced hypomorphic Lig $4^{\text {Y288C }}$ mouse strain has made it possible to characterize the effects of LigIV deficiency on the mammalian immune system. Arrest in $\mathrm{V}(\mathrm{D}) \mathrm{J}$ rearrangement is the primary cause of lymphopenia, with impaired cell survival and proliferation due to random DNA damage making additional contributions to the loss of peripheral lymphocytes. We confirm the role of LigIV in normal B cell class switching and suggest that class switching deficiencies contribute to the impaired immune function in LigIV syndrome. We also show that a hypomorphic LigIV mutation can confer strong predisposition to lymphoid malignancies. The study reveals multiple
NHEJ-dependent processes in immune system function and helps to explain the complex and multilayered immunodeficiency of the human LigIV syndrome.

\section{Methods}

Mouse strains. The Lig $4^{\mathrm{Y} 288 \mathrm{C}}$ mouse strain carries a hypomorphic Y288C mutation in the Lig4 gene on the C57BL/6J strain background (27). The C57BL/6 MD4 strain carries an anti-HEL immunoglobulin transgene ( $\mathrm{Ig}^{\mathrm{HEL}}$ ) encoding the heavy and light chains of $\operatorname{IgM}^{\mathrm{a}}$ and $\operatorname{IgD}^{\mathrm{a}}$ antibody isotypes, originally derived from the HyHEL10 hybridoma (57). The VHL strain has the same HyHEL10 antibody specificity, comprising an antiHEL $\kappa$ light chain transgene and a VDJ segment targeted to the heavychain locus and expressed with endogenous constant region exons (both gifts from Jason Cyster, UCSF, San Francisco, California, USA). C57BL/6 Rag1-null mice were previously described (58). All mice were fewer than 14 weeks old and were maintained under specific pathogen-free conditions. All the experiments were approved by the Australian National University Animal Ethics and Experimentation Committee and the Oxford University Ethical Review Committee and were conducted under a United Kingdom Home Office license.

Flow cytometry. FITC-conjugated antibodies were against the following: CD21/CD35 (7G6), CD24 (HSA, M1/69), IgD (AMS9.1), IgM ${ }^{\mathrm{b}}$ (AF672) (BD Biosciences - Pharmingen); and B220, CD8 $\alpha$, CD11b (MAC1, M1/70.15), and CD44 (CALTAG; Invitrogen). PE-conjugated antibodies were against the following: CD23 (FceRII, B3B4), CD43 (Ly-48, S7), CD5 (Ly-1, 53-7.3), $\operatorname{IgM}^{\mathrm{a}}$ (DS-1), IgD ${ }^{\mathrm{b}}$ (217-170) (BD Biosciences - Pharmingen); and CD25 (PC61-5.3) and CD4 (CALTAG; Invitrogen). APC-conjugated antibodies were against the following: IgM (II/41) (BD Biosciences - Pharmingen) and B220 (RA3-6B2) and CD4 (CALTAG; Invitrogen). Tricolor-conjugated (TC-conjugated) anti-CD8 $\alpha$ (16A) (CALTAG; Invitrogen) and biotin-conjugated anti-CD9 (KMC8) (BD Biosciences - Pharmingen) followed by streptavidin-TC (CALTAG; Invitrogen) were also used. The data were collected on FACSCalibur or FACSCanto (BD).

Mouse immunizations. Mice were immunized intraperitoneally with $50 \mu \mathrm{g}$ of alum-precipitated CGG (Jackson ImmunoResearch Laboratories Inc.) or $25 \mu \mathrm{g}$ NP-Ficoll (4-hydroxy-3-nitrophenylacetyl aminoethylcarboxymethyl-Ficoll; Biosearch Technologies) and bled from the tail vein on days 14 or 6 after immunization, respectively. Four weeks after the first immunization, mice were boosted with a secondary immunization of CGG and serum collected after 7 days.

Measurement of serum antibody titers. Serum antibody titers were measured by ELISA in 96-well plates (Greiner Bio-One) coated with $10 \mu \mathrm{g} / \mathrm{ml}$ HEL (Sigma-Aldrich), $5 \mu \mathrm{g} / \mathrm{ml} \mathrm{CGG,} 20 \mu \mathrm{g} / \mathrm{ml}$ NP-BSA (Biosearch Technologies), or $2 \mu \mathrm{g} / \mathrm{ml}$ of antibodies for mouse IgM (II/41), IgA (C10-3), $\mathrm{IgG}_{1}$ (A85-3), $\operatorname{IgG}_{2 \mathrm{a}}$ (RII-89), or $\operatorname{IgG}_{3}$ (R2-38) (all from BD Biosciences - Pharmingen) in carbonate buffer, $\mathrm{pH}$ 9.8. The plates were blocked with $1 \%$ BSA (Sigma-Aldrich) in PBS. Detection antibodies used were the biotinylated anti-mouse $\operatorname{IgM}^{\mathrm{a}}$ (DS-1), IgA (C10-1), IgG 1 (A85-1), $\operatorname{IgG}_{2 \mathrm{a} / \mathrm{b}}$ (R2-40), and $\operatorname{IgG}_{3}(\mathrm{R} 40-82)$ (all from BD Biosciences - Pharmingen) followed by an avidin-alkaline phosphatase (AP) conjugate (Sigma-Aldrich). Alternatively, AP-conjugated goat anti-mouse polyclonal antibodies for IgM (SigmaAldrich), IgA, IgG $1 \operatorname{IgG}_{2 a}$, and $\operatorname{IgG}_{3}$ (SouthernBiotech) were used. Plates were washed in PBS with $0.05 \%$ Tween-20, developed with $1 \mathrm{mg} / \mathrm{ml}$ SigmaAldrich 104 phosphatase substrate, and read at $405 \mathrm{~nm}$ with a Bio-Rad 550 plate reader. Serum antibody concentration was determined by comparison with either a serum standard of known concentration or appropriate purified mouse isotype controls (BD Biosciences - Pharmingen).

Fluorescence in situ bybridization. BAC probes (>100 kb in length) flanking the TCR $\alpha / \delta$ (RP24-336119 and RP23-9-18), TCR $\beta$ (RP24-164B11 and RP23-97020), and TCR $\gamma$ loci (RP23-97G21 and RP24-34719) were obtained 
from BACPAC Resource Center and DNA prepared with QIAGEN Midi kits. FISH probes were labeled with spectrum orange or spectrum green dyes (Abbott Diagnostics) using the BioPrime Kit (Invitrogen). After cleaning with a ChargeSwitch kit (Invitrogen), the probes were resuspended in hybridization mix (Abbott Diagnostics) and hybridized to 7- $\mu \mathrm{m}$ tissue sections. Images were taken with a Zeiss Axioskop fluorescence microscope. Sections were scored for total, paired, and unpaired probes (in normal sections greater than $90 \%$ red and green probes were closely linked).

Class switching assays. In vitro assays to assess class switching while controlling for differences in cell proliferation were performed as previously described $(33,36,50)$. Splenocytes from VHL transgenic WT and Lig $4^{\mathrm{Y} 288 \mathrm{C}}$ littermates on a mixed C57BL/6 $\times$ NOD background were labeled with CFSE using Vybrant Kit (Molecular Probes; Invitrogen). In brief, the cells were incubated at $2 \times 10^{7} \mathrm{cells} / \mathrm{ml}$ in $5 \mu \mathrm{M}$ CFSE in PBS for 10 minutes at $37^{\circ} \mathrm{C}$ and washed 3 times in RPMI 1640 (Sigma-Aldrich). The cells were then cultured at $6.5 \times 10^{5}$ cells $/ \mathrm{ml}$ in RPMI 1640 supplemented with $10 \%$ FCS (First Link [UK] Ltd.), 2 mM L-glutamine (Sigma-Aldrich), $10 \mathrm{mM} \mathrm{HEPES,}$ $\mathrm{pH} 7.4$ (Gibco; Invitrogen), $100 \mu \mathrm{g} / \mathrm{ml}$ streptomycin, $100 \mathrm{U} / \mathrm{ml}$ penicillin (Sigma-Aldrich), and $50 \mu \mathrm{M} \beta$-mercaptoethanol (Gibco; Invitrogen) at $37^{\circ} \mathrm{C}$ and $5 \% \mathrm{CO}_{2}$. Some of the cultures were stimulated with $5 \mu \mathrm{g} / \mathrm{ml}$ of LPS (Sigma-Aldrich), or $5 \mu \mathrm{g} / \mathrm{ml}$ anti-mouse CD40 antibody (HM40-3; BD Biosciences - Pharmingen), with or without $5 \mathrm{ng} / \mathrm{ml} \mathrm{IL-4} \mathrm{(Sigma-Aldrich).}$ At day 4, the cells were collected and stained with a biotin-conjugated antimouse CD19 antibody (1D3; BD Biosciences - Pharmingen) followed by polyclonal PE-conjugated goat anti-mouse $\operatorname{IgG}_{1}, \operatorname{IgG}_{2 \mathrm{a}}, \operatorname{IgG}_{2 \mathrm{~b}}$, $\operatorname{IgG}_{3}$ (SouthernBiotech), and streptavidin-TC (CALTAG; Invitrogen).

Checkpoint assays. p53 activation was used to assess G1/S checkpoint arrest, and changes in mitotic index after irradiation were used to monitor $\mathrm{G} 2 / \mathrm{M}$ progression. For $\mathrm{p} 53$ analysis, primary MEFs were grown to confluency on glass cover slips, irradiated with $10 \mathrm{~Gy}$, rested for 4 hours, fixed in $3 \%$ paraformaldehyde with $2 \%$ sucrose in PBS for 10 minutes, permeabilized with $0.2 \%$ Triton X-100 in PBS for 2.5 minutes, and washed in PBS. Cells were stained with anti-phospho-p53 antibody (Cell Signaling Technology) at 1:100 in PBS with $2 \%$ BSA for 30 minutes at $37^{\circ} \mathrm{C}$. Following PBS washing, secondary antibody incubation was with Cy3 anti-rabbit IgG at 1:200 (Sigma-Aldrich). For G2/M analysis, transformed MEFs were grown on glass cover slips to approximately $60 \%$ confluency, irradiated with 1-5 Gy, rested for 2 hours, and fixed, permeabilized, and washed as above. All samples were stained with 4'-6-diamidino-2-phenylindole
(Sigma-Aldrich) for 10 minutes at room temperature to reveal the nuclei. Cover slips were mounted in VECTASHIELD (Vector Laboratories) and cells scored under fluorescence microscope using $\times 100$ objective, counting approximately $200-500$ cells per sample.

BrdU incorporation. BrdU (Sigma-Aldrich) was supplied at $0.25 \mathrm{mg} / \mathrm{ml}$ in drinking water supplemented with $1 \%$ glucose (Sigma-Aldrich) for 1 week. Cells were fixed in $0.5 \%$ paraformaldehyde in PBS and permeabilized in fresh $3 \mathrm{M} \mathrm{HCl}$ with $0.5 \%$ Tween-20, both incubations for 20 minutes at room temperature. The acid was neutralized with $0.1 \mathrm{M}$ borax (SigmaAldrich) and the cells washed and stained with FITC-conjugated anti-BrdU antibody (3D4, BD Biosciences - Pharmingen).

Screen of mouse serum for autoantibodies. Screen for autoantibodies was performed using HEp-2000 ANA-Ro Test System slides (ImmunoConcepts; Alpha Laboratories) according to the manufacturer's protocol.

Statistics. Statistical comparisons were performed with Prism 4.0 software (GraphPad Software) using 2-tailed Student's $t$ test for comparisons of 2 data sets and ANOVA for multiple comparisons. $P \leq 0.05$ was considered significant.

\section{Acknowledgments}

We thank the members of the Cornall, Jeggo, and Goodnow groups for reviews of the manuscript; A. Gennery, A. Enders and C. Jolly for helpful discussions; and the staff of the Australian Phenomics Facility and Oxford Biomedical Services for excellent animal husbandry. This work was funded by the Wellcome Trust and the NIHR Biomedical Research Centre Programme. A. Nijnik was supported by a Wellcome Trust Prize Studentship. P.A. Jeggo is supported by the Medical Research Council, the Association for International Cancer Research, an Integrated Project EU grant, DNA Repair (LSHG-CT-2005-512113), and the United Kingdom Department of Health.

Received for publication May 21, 2007, and accepted in revised form April 1, 2009.

Address correspondence to: Richard Cornall, Henry Wellcome Building of Molecular Physiology, Roosevelt Drive, Oxford OX3 7BN, United Kingdom. Phone: 44-1865-287790; Fax: 44-1865287787; E-mail: richard.cornall@ndm.ox.ac.uk.
1. Lieber, M.R., Ma, Y., Pannicke, U., and Schwarz, K. 2003. Mechanism and regulation of human nonhomologous DNA end-joining. Nat. Rev. Mol. Cell Biol. 4:712-720.

2. Buck, D., et al. 2006. Cernunnos, a novel nonhomologous end-joining factor, is mutated in human immunodeficiency with microcephaly. Cell. 124:287-299.

3. Ahnesorg, P., Smith, P., and Jackson, S.P. 2006. XLF interacts with the XRCC4-DNA ligase IV complex to promote DNA nonhomologous end-joining. Cell. 124:301-313.

4. O'Driscoll, M., et al. 2001. DNA ligase IV mutations identified in patients exhibiting developmental delay and immunodeficiency. Mol. Cell. 8:1175-1185.

5. Ben-Omran, T.I., Cerosaletti, K., Concannon, P., Weitzman, S., and Nezarati, M.M. 2005. A patient with mutations in DNA Ligase IV: clinical features and overlap with Nijmegen breakage syndrome. Am. J. Med. Genet. A. 137A:283-287.

6. van der Burg, M., et al. 2006. A new type of radiosensitive TBNK severe combined immunodeficiency caused by a LIG4 mutation. J. Clin. Invest. 116:137-145

7. Buck, D., et al. 2006. Severe combined immu- nodeficiency and microcephaly in siblings with hypomorphic mutations in DNA ligase IV. Eur. J. Immunol. 36:224-235.

8. Enders, A., et al. 2006. A severe form of human combined immunodeficiency due to mutations in DNA ligase IV. J. Immunol. 176:5060-5068.

9. Toita, N., et al. 2007. Epstein-Barr virus-associated B-cell lymphoma in a patient with DNA ligase IV (LIG4) syndrome. Am. J. Med. Genet. A. 143:742-745.

10. Gruhn, B., et al. 2007. Successful bone marrow transplantation in a patient with DNA ligase IV deficiency and bone marrow failure. Orphanet. J. Rare Dis. 2:5.

11. Riballo, E., et al. 1999. Identification of a defect in DNA ligase IV in a radiosensitive leukaemia patient. Curr. Biol. 9:699-702.

12. Gennery, A.R. 2006. Primary immunodeficiency syndromes associated with defective DNA doublestrand break repair. Br. Med. Bull. 77-78:71-85.

13. Frank, K.M., et al. 1998. Late embryonic lethality and impaired $V(D) J$ recombination in mice lacking DNA ligase IV. Nature. 396:173-177.

14. Barnes, D.E., Stamp, G., Rosewell, I., Denzel, A., and Lindahl, T. 1998. Targeted disruption of the gene encoding DNA ligase IV leads to lethality in embryonic mice. Curr. Biol. 8:1395-1398.

15. Nussenzweig, A., et al. 1996. Requirement for Ku80 in growth and immunoglobulin $\mathrm{V}(\mathrm{D}) \mathrm{J}$ recombination. Nature. 382:551-555.

16. Zhu, C., Bogue, M.A., Lim, D.S., Hasty, P., and Roth, D.B. 1996. Ku86-deficient mice exhibit severe combined immunodeficiency and defective processing of $\mathrm{V}(\mathrm{D}) \mathrm{J}$ recombination intermediates. Cell. 86:379-389.

17. Ouyang, H., et al. 1997. Ku70 is required for DNA repair but not for $\mathrm{T}$ cell antigen receptor gene recombination in vivo. J. Exp. Med. 186:921-929.

18. Jhappan, C., Morse, H.C., 3rd, Fleischmann, R.D., Gottesman, M.M., and Merlino, G. 1997. DNAPKcs: a T-cell tumour suppressor encoded at the mouse scid locus. Nat. Genet. 17:483-486.

19. Gao, Y., et al. 1998. A targeted DNA-PKcs-null mutation reveals DNA-PK-independent functions for KU in $\mathrm{V}(\mathrm{D}) \mathrm{J}$ recombination. Immunity. 9:367-376.

20. Hsu, H.L., Gilley, D., Blackburn, E.H., and Chen, D.J. 1999. Ku is associated with the telomere in mammals. Proc. Natl. Acad. Sci. U. S. A. 96:12454-12458.

21. d'Adda di Fagagna, F., et al. 2001. Effects of DNA nonhomologous end-joining factors on telomere length and chromosomal stability in mammalian cells. Curr. Biol. 11:1192-1196. 
22. Lobrich, M., and Jeggo, P.A. 2005. Harmonising the response to DSBs: a new string in the ATM bow. DNA Repair (Amst.). 4:749-759.

23. Karanjawala, Z.E., et al. 2002. The embryonic lethality in DNA ligase IV-deficient mice is rescued by deletion of Ku: implications for unifying the heterogeneous phenotypes of NHEJ mutants. DNA Repair (Amst.). 1:1017-1026.

24. Adachi, N., Ishino, T., Ishii, Y., Takeda, S., and Koyama, H. 2001. DNA ligase IV-deficient cells are more resistant to ionizing radiation in the absence of Ku70: Implications for DNA double-strand break repair. Proc. Natl. Acad. Sci. U. S. A. 98:12109-12113.

25. Khanna, K.K., and Jackson, S.P. 2001. DNA doublestrand breaks: signaling, repair and the cancer connection. Nat. Genet. 27:247-254.

26. Soulas-Sprauel, P., et al. 2007. V(D)J and immunoglobulin class switch recombinations: a paradigm to study the regulation of DNA end-joining. Oncogene. 26:7780-7791.

27. Nijnik, A., et al. 2007. DNA repair is limiting for haematopoietic stem cells during ageing. Nature. 447:686-690.

28. Manis, J.P., et al. 1998. Ku70 is required for late B cell development and immunoglobulin heavy chain class switching. J. Exp. Med. 187:2081-2089.

29. Casellas, R., et al. 1998. Ku80 is required for immunoglobulin isotype switching. EMBOJ. 17:2404-2411.

30. Chaudhuri, J., and Alt, F.W. 2004. Class-switch recombination: interplay of transcription, DNA deamination and DNA repair. Nat. Rev. Immunol. 4:541-552.

31. Stavnezer, J., Guikema, J.E., and Schrader, C.E. 2008. Mechanism and regulation of class switch recombination. Annu. Rev. Immunol. 26:261-292.

32. Manis, J.P., Dudley, D., Kaylor, L., and Alt, F.W. 2002. IgH class switch recombination to IgG1 in DNA-PKcs-deficient B cells. Immunity. 16:607-617.

33. Cook, A.J., et al. 2003. Reduced switching in SCID B cells is associated with altered somatic mutation of recombined S regions. J. Immunol. 171:6556-6564.

34. Franco, S., et al. 2008. DNA-PKcs and Artemis function in the end-joining phase of immunoglobulin heavy chain class switch recombination. J. Exp. Med. 205:557-564.

35. Yan, C.T., et al. 2007. IgH class switching and translocations use a robust non-classical end-joining pathway. Nature. 449:478-482.

36. Soulas-Sprauel, P., et al. 2007. Role for DNA repair factor XRCC4 in immunoglobulin class switch recombination. J. Exp. Med. 204:1717-1727.

37. Li, G., et al. 2008. Lymphocyte-specific compensation for XLF/cernunnos end-joining functions in V(D)J recombination. Mol. Cell. 31:631-640.

38. Han, L., and Yu, K. 2008. Altered kinetics of nonhomologous end joining and class switch recombination in ligase IV-deficient B cells. J. Exp. Med. 205:2745-2753.

39. Pan-Hammarstrom, Q., et al. 2005. Impact of DNA ligase IV on nonhomologous end joining pathways during class switch recombination in human cells. J. Exp. Med. 201:189-194.

40. Li, H., Vogel, H., Holcomb, V.B., Gu, Y., and Hasty, P. 2007. Deletion of Ku70, Ku80, or both causes early aging without substantially increased cancer. Mol. Cell. Biol. 27:8205-8214.

41. Li, G.C., et al. 1998. Ku70: a candidate tumor suppressor gene for murine T cell lymphoma. Mol. Cell. 2:1-8.

42. Hasty, P. 2008. Is NHEJ a tumor suppressor or an aging suppressor? Cell Cycle. 7:1139-1145.

43. Nacht, M., et al. 1996. Mutations in the p53 and SCID genes cooperate in tumorigenesis. Genes Dev. 10:2055-2066.

44. Frank, K.M., et al. 2000. DNA ligase IV deficiency in mice leads to defective neurogenesis and embryonic lethality via the $\mathrm{p} 53$ pathway. Mol. Cell. 5:993-1002.

45. Difilippantonio, M.J., et al. 2000. DNA repair protein Ku80 suppresses chromosomal aberrations and malignant transformation. Nature. 404:510-514.

46. Girard, P.M., Kysela, B., Harer, C.J., Doherty, A.J., and Jeggo, P.A. 2004. Analysis of DNA ligase IV mutations found in LIG4 syndrome patients: the impact of two linked polymorphisms. Hum. Mol. Genet. 13:2369-2376.
47. Liston, A., Enders, A., and Siggs, O.M. 2008. Unravelling the association of partial T-cell immunodeficiency and immune dysregulation. Nat. Rev. Immunol. 8:545-558.

48. Westerberg, L.S., Klein, C., and Snapper, S.B. 2008. Breakdown of $\mathrm{T}$ cell tolerance and autoimmunity in primary immunodeficiency - lessons learned from monogenic disorders in mice and men. Curr. Opin. Immunol. 20:646-654.

49. Hinkley, K.S., Chiasson, R.J., Prior, T.K., and Riggs, J.E. 2002. Age-dependent increase of peritoneal B-1b $\mathrm{B}$ cells in SCID mice. Immunology. 105:196-203.

50. Lumsden, J.M., et al. 2004. Immunoglobulin class switch recombination is impaired in Atm-deficient mice. J. Exp. Med. 200:1111-1121.

51. Gu, H., and Rajewsky, K. 2004. B cell protocols. Humana Press. Totowa, New Jersey, USA. 304 pp.

52. Sharpless, N.E., et al. 2001. Impaired nonhomologous end-joining provokes soft tissue sarcomas harboring chromosomal translocations, amplifications, and deletions. Mol. Cell. 8:1187-1196.

53. Sakiyama, T., et al. 2005. Association of amino acid substitution polymorphisms in DNA repair genes TP53, POLI, REV1 and LIG4 with lung cancer risk. Int. J. Cancer. 114:730-737.

54. Gu, Y., et al. 1997. Growth retardation and leaky SCID phenotype of Ku70-deficient mice. Immunity. 7:653-665.

55. Vogel, H., Lim, D.S., Karsenty, G., Finegold, M., and Hasty, P. 1999. Deletion of Ku86 causes early onset of senescence in mice. Proc. Natl. Acad. Sci. U. S. A. 96:10770-10775.

56. Van Nguyen, T., Puebla-Osorio, N., Pang, H., Dujka, M.E., and Zhu, C. 2007. DNA damageinduced cellular senescence is sufficient to suppress tumorigenesis: a mouse model. J. Exp. Med. 204:1453-1461.

57. Goodnow, C.C., et al. 1988. Altered immunoglobulin expression and functional silencing of selfreactive B lymphocytes in transgenic mice. Nature. 334:676-682.

58. Mombaerts, P., et al. 1992. RAG-1-deficient mice have no mature B and T lymphocytes. Cell. 68:869-877. 